\title{
Sex Ratio in the Progeny of Gynogenetic Diploid Marbled Sole Limanda yokohamae Males
}

\author{
Satoshi Aida ${ }^{* 1}$ and Katsutoshi Arai ${ }^{*}+$ \\ ${ }^{*}$ Hiroshima Prefectural Fisheries Experimental Station, Ondo, 737-1207, Japan \\ ${ }^{*_{2}}$ Faculty of Applied Biological Science, Hiroshima University, 739-8528, Japan \\ (Received December 4, 1997)
}

Key words: gynogenesis, sex reversal, marbled sole, sex determination

In marbled sole, gynogenetic diploids which were produced by inhibition of the second polar body release by cold or heat shock of eggs fertilized with UV-irradiated spermatozoa gave rise to no males, while normal diploids produced by normal fertilization showed a 1:1 sex ratio." A high proportion of functional males was induced in these gynogenetic diploids by $17-\alpha$-methyltestosterone (MT) treatment. ${ }^{1)}$ As these results suggest a male-heterogametic (XX female - XY male) system for sex determination in this species, the males appearing in MT-treated gynogens were considered to be sex-reversed genetic females (functional males or pseudo-males) with the $\mathrm{XX}$ genotype. Here, we examined the sex ratio in the progeny produced from several adult pairs between normal females and MTinduced gynogenetic diploid males.

Gynogenetic males generated in January, 1993, ${ }^{1)}$ were reared in an outside tank $(4000 l)$ in the Hiroshima Prefectural Fisheries Experimental Station (HPFES) until January, 1995. We selected ten mature males ( $1 \sim 10$; body length, $17.8 \pm 1.1$ (mean \pm s.d.) $\mathrm{cm}$, body weight, $139.9 \pm 29.4 \mathrm{~g}$ ) from these two-year-old gynogenetic males based on spermiation by squeezing the abdomen. Eggs were collected from five mature females from a wild population $(\mathrm{A} \sim \mathrm{E}$; body length $25.6 \pm 1.6 \mathrm{~cm}$, body weight $488.8 \pm 107.9 \mathrm{~g}$ ). Eggs (about $40 \mathrm{~g}$ ) were fertilized with milt from each male (Table 1). No natural males were used.
Therefore, no control cross by normal pairs was performed in this study.

Incubation of fertilized eggs and rearing of fry were made in polycarbonate tanks (100 or $500 l$ ) using filtered sea water. About 2000 fry from each cross were reared in a separate tank. Density was adjusted to 1000 fry/tank at 45th day after hatching (ah). Rearing water temperature was regulated to $13.6 \sim 15.4^{\circ} \mathrm{C}$ from 1 to 60 days ah. Then, ambient water was used until the end of experiments; $13.0 \sim 17.8^{\circ} \mathrm{C}$ from $61 \sim 120$ days ah, $18.0 \sim 26.4^{\circ} \mathrm{C}$ from 121 to 240 days ah, $16.4 \sim 24.0^{\circ} \mathrm{C}$ from 241 to 300 days ah. Progeny were fed rotifer from 2 to 23 days ah, Artemia nauplii enriched with n3-HUFA from 12 to 77 days ah, copepodes collected from the sea from 27 tol 40 days ah, and then frozen oyster, mysis and moisture pellets from 60 to 310 days ah.

At the end of experiments (299 to 310 days ah), the sex of each progeny was determined not only by visually observing gonads but also by microscopically examining eggs or spermatozoa in squashed gonadal tissue preparations. No males were detected in any of the ten crosses, and almost all the progeny $(98 \%)$ were female (Table 1$)$. The remaining $2 \%$ had no gonads. These results indicate that the gynogenetic males were genetically $\mathrm{XX}$ and the resultant progeny are all female after crossing with normal $\mathrm{XX}$ females. Therefore, sex determination in marbled sole

Table 1. Sex ratio of 299- to 310-day-old progeny produced from crosses between normal females and MT-induced gynogenetic males

\begin{tabular}{|c|c|c|c|c|c|c|c|}
\hline \multicolumn{2}{|c|}{ Cross } & \multirow{2}{*}{$\begin{array}{l}\text { No. of } \\
\text { progeny }\end{array}$} & \multicolumn{3}{|c|}{ Sex } & \multirow{2}{*}{$\begin{array}{c}\text { Body length } \\
\text { mean } \pm \text { s.d.(cm) }\end{array}$} & \multirow{2}{*}{$\begin{array}{l}\text { Body weight } \\
\text { mean } \pm \text { s.d.(g) }\end{array}$} \\
\hline Female & $\times$ Gyno. male & & Female & Male & $\mathrm{ND}^{*}$ & & \\
\hline $\mathbf{A}$ & 1 & 58 & 58 & 0 & 0 & $8.9 \pm 1.4$ & $20.0 \pm 9.9$ \\
\hline $\mathrm{A}, \mathrm{B}$ & 2 & 51 & 50 & 0 & 1 & $8.6 \pm 1.3$ & $16.0 \pm 0.8$ \\
\hline B & 3 & 54 & 51 & 0 & 3 & $9.2 \pm 1.6$ & $20.6 \pm 12.0$ \\
\hline B & 4 & 38 & 38 & 0 & 0 & $8.0 \pm 0.9$ & $11.8 \pm 4.7$ \\
\hline C & 5 & 82 & 80 & 0 & 2 & $6.9 \pm 1.1$ & $7.2 \pm 3.8$ \\
\hline $\mathrm{D}$ & 6 & 180 & 177 & 0 & 3 & $7.4 \pm 0.1$ & $9.7 \pm 4.7$ \\
\hline $\mathrm{D}$ & 7 & 109 & 106 & 0 & 3 & $8.5 \pm 0.1$ & $16.2 \pm 7.6$ \\
\hline E & 8 & 42 & 40 & 0 & 2 & $9.3 \pm 1.6$ & $22.1 \pm 14.9$ \\
\hline $\mathrm{E}$ & 9 & 12 & 11 & 0 & 1 & $8.6 \pm 2.0$ & $18.7 \pm 17.7$ \\
\hline E & 10 & 19 & 19 & 0 & 0 & $11.2 \pm 3.5$ & $29.8 \pm 5.3$ \\
\hline
\end{tabular}

- Not determined; no gonads were observed.

Corresponding author.

* R. Goto et al.: Abst. Metg. Japan. Soc. Fisheries Sci., April, 1997, p. 65 (in Japanese). 
is due to male heterogamety (XX-XY system).

In hirame flounder Paralichthys olivaceus, when genetic females were reared under high temperature and/or high density conditions, sex reversal to physiological males was frequently induced..$^{2-5)}$ In contrast, marbled sole in the present study gave stable production of an all female population, and this suggests little influence of environmental factors on the sex ratio. However, an increase in incidence of males under high temperature $\left(25^{\circ} \mathrm{C}\right)$ conditions during sex differentiation was recently reported in normally fertilized marbled sole progeny. ${ }^{*}$ Therefore, the effect of en vironmental factors on sex in this species should be investigated further using genetically $\mathrm{XX}$ males.

\section{References}

1) Y. Kakimoto, S. Aida, K. Arai, and R. Suzuki: J. Fac. Appl. Biol. Sci., Hiroshima Univ., 33, 113-124 (1994) (in Japanese).

2) E. Yamamoto, R. Masutani, and R. Hirano: Suisan-ikushu (Fish Genet.Breed. Sci.), 16, 57-62 (1991) (in Japanese).

3) E. Yamamoto: Suisan-ikushu (Fish Genet. Breed. Sci.), 18, 13-23 (1992) (in Japanese).

4) E. Yamamoto: Bull. Tottori Pref. Fish. Exp. Stn., 34, 1-145 (1995) (in Japanese).

5) K. Tabata and A. Mizuta: Bull. Natl. Res. Inst. Aquacult., Suppl. 3, 43-52 (1997). 